„TURYZM" 1992, z. 1

Jerzy Wyrzykowski

\title{
WROCEAW AS A LARGE SIGHTSEEING CENTER
}

WROCEAW, GRAND CENTRE CHOROGRAPHIQUE

WROCEAW JAKO WIELKIE CENTRUM KRAJOZNAWCZE

Wroclaw, the fourth most populated town in Poland, is set in the centre of Lower Silesia, at the mouths of Oława, Slęża, Bystrzyca and Widawa rivers, tributaries of the Odra River, at a distance of 100-150 $\mathrm{km}$ from the Sudetes Mountains. The town is a major regional center of industry, science and culture. There were 642,300 inhabitants in Wrockaw in 1989. In 1988 the state economy employed 265,300 workers, 81,600 in industry, 33,200 in construction, 15,200 in transportation, and 26,400 in commerce.

Wrocław was considered by the Polish Indicative Tourist Plan, as one of the most important localities and touristic areas with which each inhabitant of our country should have been acquainted at school, and which should be an important goal for foreign tourism.

The localities included in the first category are called "large sightseeing centres". The paper presents the elements of Wrocław's touristic attractiveness and its present touristic utilization.

Wrockaw in one of the largest communication junctions in the country. 12 main road routes and 9 railway lines cross here. A number of important international roads also pass through Wrocław: the $\mathrm{E} 40$ from Dunkirk to Lvov and Kharkov, and the E 67 from Prague to Warsaw. In addition there are major railways linking Western, Central, Eastern and South-Eastern Europe, including lines from Berlin, Frankfurt-am-Main, Munich, Prague, Budapest, Bucharest, Burgas, Lvov, Kiev, and Moscow. Wrockaw posseses an airport as well as river harbours, the Odra river being connected with the West Europe an waterway system.

Wrocław has rich and differentiated touristic attractions and numerous architectural monuments, interesting museums and exhibitions as 
well as landscape and natural features. The tourist attraction of the town is increased by a wealth of cultural and folkloristic spectacles, theatres and concert halls and the possibilities of Odra River trips.

Table I

The most important architectural monuments in Wroclaw

Lesi plus importants monuments de l'architecture à Wrocław

\section{Objects of European significance}

Cathedral Island:

Cathedral Church of St. John Baptist

Collegiate Church of St. Cross with lower Church of Byzantium - Ukraine of St. Cross

Sand Island:

Augustinian Convent, Holy Virgin Mary Church and convent building Old and New Town:

The Jesuit College (University at present)

Town Hall

Objects of general national significance

Cathedral Island:

Building of Chapter

Old and New Town:

Cathedral Church of St. Mary Magdalena

Garrison Church of St. Elizabeth (being reconstructed)

The Convent of Crusaders with Red Star (presently the Ossolineum Library)

St. Vincent Church (reconstructed)

The Dominican Convent with St. Adalberth Church

The Franciscan Church of St. Stanislav, St. Waclaw, and St. Dorota

Church of Knights of St. John of Jerusalem

Old Exchange

The tanement-houses in Rynek: Pod Gryfami, Pod Złotym Słoncem, Siedmiu Elektorów, Kuźnicza Street, Pod Srebrnym Hełmem, Solny Square

Source: Loziński, Milobęzk 1, 1967.

The most important architectural monuments according to $€ \mathrm{ozin}-$ ski and Miłobędzki (1967) are presented by Table I. 5 buildings or building complexes are included as objects of European significance, and a further 14 are included as objects of national significance. There is a particular concentration of monuments in the Old Town and on Cathedral Island (Ostrów Tumski). The complex of representative Gothic buildings (among other things the Town Hall and Cathedral) belongs to one of the largest not only in Poland but also in Europe. In the group of more recent architectonic objects the People's Hall should be mentioned. It was built in $1912-1913$ and is one of the world's first gigantic reinforced concrete constructions. 
Fig. 1. Wrocław. Map of the city centre

Dessin 1. Wrocław. Plan de la ville

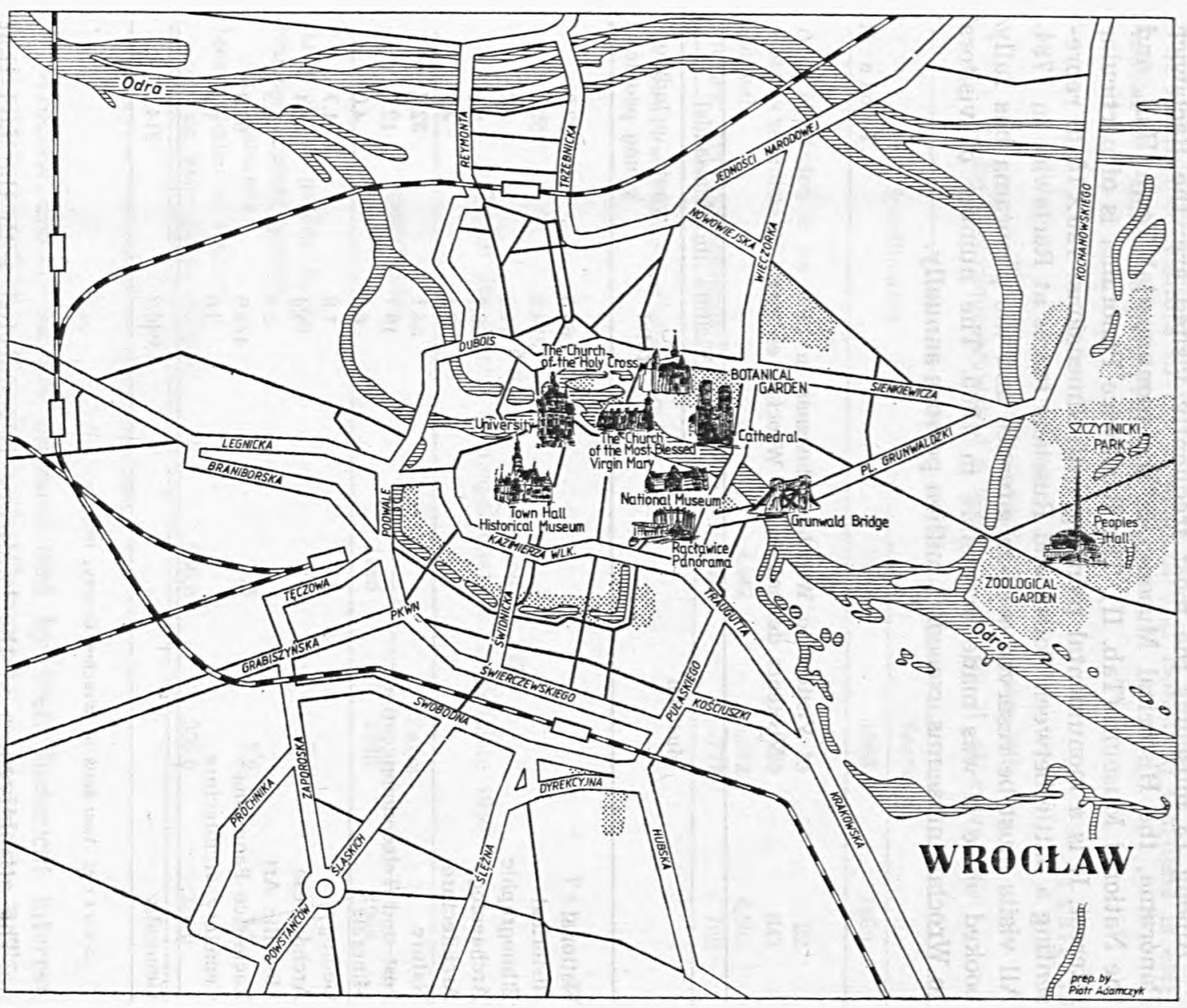

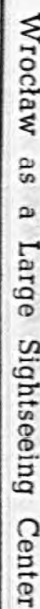


Among 13 museums the most frequently visited are: the Racławice Panorama, the Historical Museum in the monumental Town Hall, and the National Museum (Tab. II). The Racławice Panorama is of particular interest. It is a monumental painting with dimensions: $120 \times 15 \mathrm{~m}$ representing a battle between Polish and Russians forces at Racławice in 1794 . All visits must be reserved well in advance and the panorama has fully booked since it was made accessible in 1985 . The number of visitors to Wrocław museums exceeds 1 million persons annually.

Table II

Visitors to Wrocław Museums in 1989

Visiteurs des musées de Wrocław en 1989

\begin{tabular}{lrr}
\hline & Visitors & (in thousands) \\
\cline { 2 - 3 } & total & $\begin{array}{r}\text { youth including } \\
\text { young people }\end{array}$ \\
\hline National & 66.5 & 22.0 \\
Historical & 314.8 & 50.5 \\
Ethnographic & 11.5 & 5.2 \\
Archaeology & 28.2 & 6.9 \\
Architecture & 37.1 & 4.1 \\
Nature & 53.1 & 32.7 \\
Post and Telecommunications & 19.1 & 12.0 \\
Minerals & 6.0 & 4.0 \\
Geology & 1.8 & 1.7 \\
Archdiocese & 18.4 & 3.4 \\
Medallic Art & 5.3 & 2.5 \\
Racławice Panorama & 475.9 & 68.0 \\
Cemetery architecture & 3.0 & 1.5 \\
\hline Generally & $1,040.7$ & 214.5 \\
\hline
\end{tabular}

Sour ce: Year-book of Wroclaw County, 1990.

The attractiveness of the landscape is connected with the fact that the town is situated on the Odra River and tributaries with a large number of picturesque bridges (over 90), including the unique Suspension Grunwald Bridge, and large green areas.

Among the 23 parks, Szczytnicki Park is of particular significance because of its differentiated tree cover. It is the fourth park in Europe in this respect. The Zoological and Botanical Gardens also possess natural attractions. The zoo is the largest in Poland and one of the largest in Europe. The Botanical Garden is also one of the largest in the country. 
The number of visitors to the Zoological and Botanical Gardens is estimated as 1 million a year (Tab. III, IV).

The Wrocław Zoological Garden (on 31 XII)

Jardin Zoologique Municipal à Wrocław (état au 31 décembre 1989)

\begin{tabular}{lrrr}
\hline \multirow{2}{*}{ Specification } & \multicolumn{1}{c}{ Years } \\
\cline { 2 - 4 } & \multicolumn{1}{c}{1985} & 1988 & 1989 \\
\hline & 32 & 33 & 32 \\
Area of garden in ha & 612 & 689 & 643 \\
Species of animals & 4,442 & 5,372 & 4,502 \\
Animals & 518 & 777 & 788 \\
Tickets sold (in thousands) & \\
\hline
\end{tabular}

S o u c e: Year-book of Wroclaw County, 1990.

Botanical Garden (on 31 XII)

Jardin des Plantes Municipal (état au 31 décembre 1989)

\begin{tabular}{lccc}
\hline \multirow{2}{*}{ Specification } & \multicolumn{3}{c}{ Years } \\
\cline { 2 - 4 } & 1985 & 1988 & 1989 \\
\hline $\begin{array}{l}\text { Area of the garden in ha } \\
\begin{array}{l}\text { Number of plant species } \\
\quad \text { in thousands }\end{array}\end{array}$ & 7.1 & 7.1 & 7.1 \\
$\begin{array}{l}\text { Mean number of visitors } \\
\text { during year (in thousands) }\end{array}$ & 7.2 & 7.2 & 7.2 \\
\hline
\end{tabular}

S o u r ce: Year-book of Wroclaw County, 1990.

Wrocław cemeteries are characterized by their historical interest, particularly the Jewish Cemetery, the Cemetery - mausoleum Russian Soldiers, the Cemetery of Polish Soldiers and the St. Lawrence Cemetery.

Wrocław is the largest cultural centre of the Odra River Region. There are 11 active theatres and musical institutions (Tab. V), and numerous cultural and folkloristic events are organized here (Tab. VI). Among theatres, the best known are: the Pantomima Theatre directed by $\mathrm{H}$. Tomaszewski and the Laboratory Theatre with J. Grotowski as director. In 1989 the Opera, Operetta, Philharmonic and Puppett Theatres had the largest audiences. Among theatrical and musical festivals of 
the greatest European fame is the „Oratorio-Cantata Festival „Wratislavia Cantans" (Tab. VI).

Theatres and musical institutions (1989)

Théâtres et établissements de musique (1989)

\begin{tabular}{lrr}
\hline \multicolumn{1}{c}{ Specification } & Places & $\begin{array}{c}\text { Audience } \\
\text { (in thousands) }\end{array}$ \\
\hline Polski Theatre & 1,212 & 55.3 \\
Kameralny Theatre & 301 & 40.0 \\
Współczesny Theatre & 317 & 67.2 \\
Wrocław Theatre of Pantomime & 297 & 19.7 \\
Wrocław Theatre of Puppets & 30 & 74.9 \\
Second Studio of Wrocław & & 2.0 \\
Centre of Open Theatre "Kalambur" & & \\
$\quad$ Scene: & 96 & 3.4 \\
$\quad$ Large & 48 & \\
$\quad$ Small & & 101.8 \\
State Opera & & 0.6 \\
$\quad$ Scene: & 700 & 96.3 \\
$\quad$ Large & 120 & 88.1 \\
$\quad$ Small & 600 & 13.0 \\
Wrocław Operetta & 501 & 576.1 \\
State Philharmonic & & \\
Cantores Minores Wratislavienses & & \\
\hline Total & 4,222 & \\
\hline
\end{tabular}

S ource: Year-book of Wroclaw County, 1990.

Numerous itineraries and programmes for visiting the town, based on above mentioned touristic values, have been proposed.

C z e rwiński (1989) worked out 8 itineraries of several hourseach; C etwiński (1985) preparated 6 perambulations. Taking into account the existence of interesting excursions in the vicinity of Wrocław, Czerwiński proposes 6 trips by car to Brzeg, Henryków, Lubiąż, Milicz, Oleśnica, Sobótka and Trzebnica; one needs at least a 3 days' stay in Wrocław to complete these.

There are 5,000 beds available in Wrocław throughout the year (Tab. VII). Among the 20 accommodation facilities, excluding guest rooms, there are in principle all the most important kinds of accommodation sought by tourists from hotels to camp sites. In the 1980 s there was a noticeable and continuous decrease in the number of beds available for tourists (Tab. IX). The catering business is represented by 61 restau- 
Festivals, fairs and cultural events

Festivals, foires et festins

Month Kind of spectacle

\begin{tabular}{ll}
\hline February & $\begin{array}{l}\text { Festival of Polish Contemporary Music; "Musica Polonica Nova" } \\
\text { (every two years) }\end{array}$ \\
March & Review of Actors Song \\
April & Jazz Festival "Jazz nad Odra"; Polish Youth Review of the Song \\
May & The Wrocław Days; Piast Fair; "Cepeliada" \\
May-June & Festival of Polish Contemporary Plays \\
July & Wrocław Flower Festival \\
September & International Oratoris-Cantata Festival "Wratislavia Cantans"; Wro- \\
& chaw Days of Tourism; International Meeting of Open-Theatre; \\
& Wroclaw Garden Fairs; Trzebnica Orchards Festival \\
October & Jazz Film Saloon; International Triennale of Drawings \\
November & Polish Meetings of Musiciens Families \\
December & Days of Music of Old Masters (each two years) \\
\hline
\end{tabular}

Source: Czerwiński, 1989.

Table VII

Touristic facilities in Wrocław (situation at 31 XII 1989)

Base de couchage a Wroclaw (état au 31 décembre 1989)

\begin{tabular}{|c|c|c|c|}
\hline \multirow{2}{*}{ Kind of facilities } & \multirow{2}{*}{$\begin{array}{c}\text { Number of } \\
\text { facilities }\end{array}$} & \multicolumn{2}{|c|}{ Number of beds } \\
\hline & & whole year & season \\
\hline Hotels & $\sqrt{7}$ & 1,916 & - \\
\hline Motels & 1 & 144 & - \\
\hline Houses of excursions & 5 & 370 & - \\
\hline Youth shelters & 2 & 115 & - \\
\hline Camp sites & 2 & 52 & 479 \\
\hline Guests room: & & 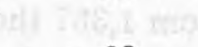 & \\
\hline state-owned & & 85 & - \\
\hline private & & 1,390 & - \\
\hline Other facilities & 2 & 158 & 360 \\
\hline Total & 20 & 4,230 & 839 \\
\hline
\end{tabular}

Source: Year-book of Wroclaw County, 1990.

rants, bars and cafés with dining facilities for 6,200 (Tab. VIII). The largest number of seats are in cafe's, with 2,600 and in restaurants, with 2,300. 
Catering facilities in Wrockaw (situation at 31 VIII 1989)

Base gastronomique offerte aux touristes à Wrocław (état au 31 août 1989)

\begin{tabular}{lll}
\hline Kind of facilities & $\begin{array}{c}\text { Number of } \\
\text { facilities }\end{array}$ & $\begin{array}{c}\text { Number of } \\
\text { gastronomic } \\
\text { places }\end{array}$ \\
\hline Restaurants & 20 & 2,303 \\
Bars & 18 & 1,274 \\
Cafés & 23 & 2,614 \\
\hline Total & 61 & 6,191 \\
\hline
\end{tabular}

S our c e: Touristic guide-book of Lower Silesia, 1989.

Table IX

Utilization of tourist facilities in Wrocław

Utilisation de l'équipement touristique à Wrocław

\begin{tabular}{lccc}
\hline \multicolumn{1}{c}{ Specification } & \multicolumn{1}{c}{ Years } \\
\cline { 2 - 4 } & 1980 & 1985 & 1989 \\
\hline Beds in tourist facilities & 5,888 & 5,259 & 5,069 \\
$\begin{array}{l}\text { Users of beds available (in } \\
\quad \text { thousands) }\end{array}$ & 346.0 & 313.6 & 287.2 \\
Overnight stays (in thousands) & $1,356.7$ & $1,195.4$ & 939.5 \\
\hline
\end{tabular}

S ource: Year-book of Wroclaw County, 1990.

The socio-economic crisis of the country and a serious decrease in the standard of living has influenced tourist trends and the use tourist facilities. In the $1980 \mathrm{~s}$ the number of persons using the accommodation decreased from 346,000 to 287,200 (a fall of about $17 \%$ ) and number of overnight stays from 1,357 thousand to 940 thousand (a fall of about $31 \%$ ).

In the second half of the 1980s the use of various tourist facilities declined, particularly after 1989 because of the introduction of the free market economy. The numbers visiting the Wrockaw County Museums increased significantly during 1985-1988 from 670,000 to $1,083,000$, largely in conjunction with the opening of the Racławice Panorama. However, in 1989 a slight decrease in the number of visitors to $1,059,000$ was also noted.

Audiences in theatres and musical institutions increased from 646,000 in 1985 to 669,000 in 1988 , but then in 1989 decreased to 576,000 .

The number of Polish Airlines "LOT" passengers using Wrockaw 
airport significantly increased between 1985-1988 (about $+42 \%$ ), but in 1989 decreased to the level of 1985 (Tab. X). The number of passengers taking on the River Odra in the vicinity of Wrockaw in second half of the $1980 \mathrm{~s}$ was in principle similar, that is, about 200,000 persons yearly (Tab. XI). The utilization of Botanical Garden was similar, some 350,000 a year.

Polish Airlines "LOT"

Lignes Aériennes Polonaises „LOT"

\begin{tabular}{ccc}
\hline \multirow{2}{*}{ Specification } & \multicolumn{2}{c}{ Passengers } \\
\cline { 2 - 3 } & departures & arrivals \\
from Wroclaw & at Wrocław \\
\hline
\end{tabular}

Total:

$\begin{array}{lll}1985 & 35,501 & 37,306 \\ 1988 & 51,528 & 52,196 \\ 1989 & 37,219 & 37,123\end{array}$

Lines:

\begin{tabular}{lrr} 
Wrocław-Warsaw & 36,683 & 36,695 \\
other flights & 536 & 428 \\
\hline
\end{tabular}

S our ce: Year-book of Wroclaw County, 1990.

Table XI

Passengers trips on Wrocław waterways (the Odra River)

Transport des passagers par les ports de Wrocław (le fleuve Oder)

\begin{tabular}{lccc}
\hline \multirow{2}{*}{ Specification } & \multicolumn{3}{c}{ Years } \\
\cline { 2 - 4 } & 1985 & 1988 & 1989 \\
\hline $\begin{array}{l}\text { Downstream river passengers } \\
\quad \text { (in thousands) }\end{array}$ & 94.4 & 91.3 & 92.1 \\
$\begin{array}{l}\text { Upstream river passengers } \\
\quad \text { (in thousands) }\end{array}$ & 94.4 & 91.3 & 92.1 \\
$\begin{array}{c}\text { Passengers in rented ships } \\
\text { (in thousands) }\end{array}$ & 7.9 & 7.8 & 7.0 \\
\hline
\end{tabular}

S ou r ce: Year-book of Wroclaw County, 1990.

An increasing tendency was visible only in the Zoological Garden where number of tickets sold during 1985--1989 increased about 52\%.

For comparison, Table XII presents information about the number of beds in tourist facilities and their utilization in 8 large Polish sight- 
seeing centres. The data show that Wrockaw is in fourth position after Warsaw, Poznań and Cracow.

Table XII

Tourist facilities and their utilization in large Polish sightseeing centres (current situation)

Equipement touristique et son utilisation dans les grands centres chorographiques da la Pologne

\begin{tabular}{lcccr}
\hline $\begin{array}{c}\text { Large sightseeing } \\
\text { center }\end{array}$ & $\begin{array}{c}\text { Number of } \\
\text { inhabitants (in } \\
\text { thousands) }\end{array}$ & $\begin{array}{c}\text { Beds } \\
\text { available }\end{array}$ & $\begin{array}{c}\text { Number of } \\
\text { visitors staying } \\
\text { (in thousands) }\end{array}$ & $\begin{array}{c}\text { Overnight } \\
\text { stays (in } \\
\text { thousands) }\end{array}$ \\
\hline Gdańsk (1988) & 461.5 & 4,674 & 191.4 & 580.2 \\
Kraków (1989) & 745.6 & 6,209 & 422.6 & 939.2 \\
Lublin (1988) & 339.5 & 2,741 & 117.8 & 288.4 \\
Poznań (1989) & 586.9 & 14,752 & 354.5 & 1609.5 \\
Szczecin (1988) & 409.5 & 3,257 & 176.9 & 384.6 \\
Toruń (1989) & 200.9 & 1,770 & 83.7 & 162.0 \\
Warszawa (1988) & 1651.2 & 13,014 & 710.8 & $16,500.4$ \\
Wrocław (1989) & 642.3 & 5,069 & 287.2 & 939.5 \\
\hline
\end{tabular}

Source: Year-books of counties $(1989,1990)$.

The material presented suggests that Wrockaw and its region possesses abundant touristic attractions, adequate transportation accessibility and significant infrastructural base for tourism. These facilities are not fully used, particularly the accommodation available. This is obviously connected with the socio-economic crisis and the falling standard of living.

However, in future it is possible to expect an increase in domestic tourism and the development of foreign tourism. The improvement in tourist attractions, the amelioration of the infrastructural base, and the preparation of appropriate tourist advertising for the city should meet present requirements.

\section{REFERENCES}

Cetwiński C., 1985, Wroclawskie spacery, Centrum Informacji Turystycznej, Wrocław.

Czerwiński J., 1989, Wrocław i okolice. Przewodnik, wyd. "Sport i Turystyka", Warszawa. 
Łoziński J. Z., Miłobędzki A., 1967, Atlas zabytków architektury w Polsce, wyd, „Polonia”, Warszawa.

Plan kierunkowy zagospodarowania turystycznego Polski, 1971, GKKFiT, Zakład Zagospodarowania Turystycznego, Wrocław.

Rocznik statystyczny województwa wrocławskiego, 1990, Wojewódzki Urząd Statystyczny we Wrocławiu, Wrocław.

Doc. dr hab. Jerzy Wyrzykowski

Wpłynęło:

Instytut Geograficzny

30 października $1991 \mathrm{r}$.

Uniwersytet Wrocławski

Plac Uniwersytecki 1

50-137 Wrocław

RESUMÉ

Wrocław est l'un de grands centres chorographiques de la Pologne. La ville doit ses attraits touristiques à sa situation avantageuse au croisement des voies de com. munication, à ses valeurs touristiques et aux bases de couchage et gastronomique bien développées. Parmi les valeurs touristiques de distinguent les monuments de l'architecture et de la construction de classe européenne (l'hôtel de ville, la cathédrale, entre autres), les musées avec la peinture monumentale du Panorama de Racławice, les valeurs de paysage (la situation sur l'Odra et ses affluents, les ponts pittoresques, les parcs nombreux) et naturelles (le Jardin des plantes, le Jardin zoologique, le parc de Szczytniki).

Ainsi que dans tout le pays, dans les années quatre-vingts, le mouvement touristique lié à l'exploitation de la base de couchage a sensiblement baissé. Pendant une année, moins de 1 million de personnes ont loué leur place de couchage. Dans les autres objets touristiques, la baisse d'affluence était moins notable; dans le Jardin zoologique le nombre de visiteurs a considérablement augmenté. Chaque année les musées sont visités par plus d'un million de personnes. Le même nombre de visiteurs reçoivent ensemble le Jardin zoologique et le Jardin des plantes.

Parmi les plus grands centres chorographiques de la Pologne, eu égard à la grandeur de la base et du mouvement touristique, Wrocław se place au quatrième rang après Varsovie, Poznań et Cracovie.

Traduit par Lucjan Kowalski

\section{STRESZCZENIE}

Wrocław jest jednym z wielkich centrów krajoznawrzy h Polski. Na dużą atrakcyjność turystyczną miasta składają sį̨: dogodne położenie na skrzyżowaniu szlaków komunikacyjnych, wysokie walory turystyczne oraz rozwinięta baza noclegowa i gastronomiczna. Wśród walorów turystycznych wyróżniają się europejskiej klasy 
zabytki architektury i budownictwa ( $\mathrm{m}$. in. ratusz i katedra), obiekty muzealne $\mathrm{z}$ monumentalnym malowidłem Panoramy Racławickiej, walory krajobrazowe (położenie nad Odrą i jej dopływami, malownicze mosty, liczne parki) i przyrodnicze (Ogród Botaniczny, Ogród Zoologiczny, Park Szczytnicki).

Podobnie jak w calym kraju, w latach osiemdziesiątych znacznie obniżył się ruch turystyczny związany $\mathrm{z}$ wykorzystaniem bazy noclegowej. Liczba udzielonych noclegów w ciągu roku spadła poniżej $1 \mathrm{mln}$. W innych rodzajach obiektów turystycznych spadek frekwencji był mniej widoczny, a w Ogrodzie Zoologicznym liczba zwiedzających nawet znacznie wzrosła. Obiekty muzealne odwiedza rocznie ponad milion osób, podobną frekwencję mają również łącznie Ogród Zoologiczny i Ogród Botaniczny.

$\mathrm{Z}$ porównania wielkości bazy i ruchu turystycznego $\mathrm{w}$ grupie wielkich centrów krajoznawczych w Polsce wynika, że Wrocław zajmuje pod tym względem czwarte miejsce, po Warszawie, Poznaniu i Krakowie. 